\title{
Saccharopolyspora jiangxiensis sp. nov., isolated from grass-field soil
}

Correspondence

Jianli Zhang

zhangjianli@bit.edu.cn

\author{
Jianli Zhang, ${ }^{1}$ Dongdong $\mathrm{Wu}^{1}$ and Zhiheng $\mathrm{Liu}^{2}$ \\ ${ }^{1}$ School of Life Science and Technology, Beijing Institute of Technology, Beijing 100081, PR China \\ ${ }^{2}$ State Key Laboratory of Microbial Resources, Institute of Microbiology, Chinese Academy of \\ Sciences, Beijing 100101, PR China
}

The genus Saccharopolyspora was established by Lacey \& Goodfellow (1975) and was assigned to the family Pseudonocardiaceae (Embley et al., 1988; Warwick et al., 1994). At the time of writing, the genus encompasses 14 species with validly published names: Saccharopolyspora antimicrobica Yuan et al. 2008; S. cebuensis Pimentel-Elardo et al. 2008; S. erythraea (Waksman 1923) Labeda 1987; S. flava Lu et al. 2001; S. gregorii Goodfellow et al. 1989; S. halophila Tang et al. 2009; S. hirsuta subsp. kobensis (ex Iwasake and Mori 1979) Lacey 1989; S. hordei Goodfellow et al. 1989; S. rectivirgula (Krasil'nikov and Agre 1964) Korn-Wendisch et al. 1989; S. shandongensis Zhang et al. 2008; S. spinosa Mertz and Yao 1990; S. spinosporotrichia Zhou et al. 1998; S. taberi (Labeda 1987) Korn-Wendisch et al. 1989; S. thermophila Lu et al. 2001; and S. hirsuta Lacey and Goodfellow 1975 (the type species). Representatives of these species form a distinct phyletic line within the evolutionary radiation encompassed by the family Pseudonocardiaceae and can be distinguished using a combination of biochemical, morphological and physiological properties (Lu et al., 2001). Members of the genus Saccharopolyspora are potentially rich sources of natural products, but only erythromycin (produced by S. erythraea) is currently of commercial importance (Embley, 1992).

An actinomycete, strain $\mathrm{W} 12^{\mathrm{T}}$, isolated during an ecological survey of soil actinomycetes in China, was found to

The GenBank/EMBL/DDBJ accession number for the 16S rRNA gene sequence of strain $\mathrm{W}_{12}{ }^{\top}$ is EF143926. have morphological and chemical properties consistent with its assignment to the genus Saccharopolyspora. In the present investigation, a polyphasic approach was used to determine the taxonomic position of this soil isolate. Genotypic and phenotypic data indicated that this strain should be classified as a novel species of the genus Saccharopolyspora.

Strain $\mathrm{W} 12^{\mathrm{T}}$ was isolated on a glucose-yeast extract-malt extract medium (GYM) agar plate, which had been seeded with a soil suspension and incubated at $28{ }^{\circ} \mathrm{C}$ for 14 days. The soil sample was collected from a field of grass in Jiangxi Province, China. Strain $\mathrm{W} 12^{\mathrm{T}}$ was maintained on GYM agar at $4{ }^{\circ} \mathrm{C}$ and as suspensions of mycelial fragments in $20 \%(\mathrm{v} / \mathrm{v})$ glycerol at $-20{ }^{\circ} \mathrm{C}$. Biomass for the chemotaxonomic and molecular systematic studies was prepared as described by Zhang et al. (2002) with the modification that the strain was grown in shake flasks containing GYM broth.

Micromorphological and colonial properties were examined on GYM agar, modified Sauton's agar (Mordarska et al., 1972) and standard media used in the International Streptomyces Project (Shirling \& Gottlieb, 1966), for 714 days at $28{ }^{\circ} \mathrm{C}$. The micromorphology was examined using the cover-slip technique of Kawato \& Shinobu (1959), following the procedure described by Zhou et al. (1998), using a Zeiss Axioskop 20 light microscope. The spore-chain morphology was also investigated by examining gold-coated, dehydrated specimens of the organism, using a Hitachi S-570 scanning electron microscope. 
The novel strain was examined for a range of phenotypic properties by using previously described procedures (Lacey \& Goodfellow, 1975; Lu et al., 2001; Zhang et al., 2003). Acid production from carbohydrates was assessed using methods described by Gordon et al. (1974), while the utilization of sole carbon sources was investigated as described by Gordon \& Mihm (1957). Tolerance of pH, temperature and $\mathrm{NaCl}$ was investigated using GYM agar plates incubated for up to 14 days. Resistance to lysozyme was determined by using the method of Gordon et al. (1974). Resistance to antibiotics was examined by placing antibiotic-impregnated filter-paper discs (Goodfellow \& Orchard, 1974) on GYM agar and assessing the results after 14 days incubation at $28{ }^{\circ} \mathrm{C}$.

Genomic DNA preparation, PCR-mediated amplification of the $16 \mathrm{~S}$ rRNA gene and purification of the PCR product from strain $\mathrm{W} 12^{\mathrm{T}}$ were carried out as described by Rainey et al. (1996) and the PCR product was sequenced directly using the method of $\mathrm{Lu}$ et al. (2001). Sequence gel electrophoresis was performed and the nucleotide sequences were obtained automatically by using an Applied Biosystems DNA sequencer (model 377) and software provided by the manufacturer. The resultant $16 \mathrm{~S}$ rRNA gene sequence was aligned manually against corresponding sequences from members of the genus Saccharopolyspora and from representatives of genera in the family Pseudonocardiaceae, available from the GenBank/ EMBL/DDBJ databases, using CLUSTAL_X, version 1.8 (Thompson et al., 1997). Phylogenetic trees were inferred using the maximum-likelihood (Felsenstein, 1981) and neighbour-joining (Saitou \& Nei, 1987) treeing algorithms. Evolutionary distance matrices were generated as described by Kimura (1980). The resultant unrooted tree topologies were evaluated by means of bootstrap analysis (Felsenstein, 1985) of the neighbour-joining dataset (based on 1000 resamplings), using the SEQBOOT and CONSENSE options. The PHYLIP package (Felsenstein, 1993) was used for all phylogenetic analyses.

Chemotaxonomic studies were performed with strain $\mathrm{W} 12^{\mathrm{T}}$ to determine whether its chemical profile was typical of members of the genus Saccharopolyspora (Lacey \& Goodfellow, 1975). Isomers of diaminopimelic acid and whole-organism sugars were analysed according to the procedures developed by Hasegawa et al. (1983) and Lechevalier \& Lechevalier (1980). Mycolic acids were checked by using the acid methanolysis method of Minnikin et al. (1975). Polar lipids were examined using two-dimensional TLC and were identified according to the method of Minnikin et al. (1984). Isoprenoid quinones were extracted and purified as described by Collins et al. (1987); purified menaquinones were determined using reversed-phase HPLC (Wu et al., 1989). The fatty acids were extracted, purified, methylated and quantified by means of GC using the standard Microbial Identification System (MIDI; Sasser, 1990; Kämpfer \& Kroppenstedt, 1996).
The DNA-DNA relatedness between the isolate and representatives of phylogenetically close Saccharopolyspora species (S. antimicrobica KCTC $19303^{\mathrm{T}}$, S. hirsuta subsp. hirsuta ATCC $27875^{\mathrm{T}}$, S. shandongensis CGMCC $4.3530^{\mathrm{T}}$ and S. spinosa DSM $44228^{\mathrm{T}}$ ) was determined using a thermal denaturation procedure (De Ley et al., 1970; Huß et al., 1983) with a UV-1206 spectrophotometer (Shimadzu) fitted with a TB-85 thermobath and standard software (Jahnke, 1992); the results were expressed as means of two determinations. The $\mathrm{G}+\mathrm{C}$ content of the DNA was determined using the thermal denaturation method (Marmur \& Doty, 1962) with Escherichia coli AS 1.365 as the standard.

An almost-complete 16S rRNA gene sequence (1419 nt) was obtained for strain $\mathrm{W} 12^{\mathrm{T}}$. Phylogenetic analysis in which this sequence was compared with corresponding sequences for representatives of the genera classified in the suborder Pseudonocardineae showed that it contains all of the signature nucleotides expected for members of this taxon (Stackebrandt et al., 1997) and, more specifically, those that are characteristic of members of the family Pseudonocardiaceae (Embley et al., 1988; Warwick et al., 1994) and the genus Saccharopolyspora (Lacey \& Goodfellow, 1975). The high levels of $16 \mathrm{~S}$ rRNA gene sequence similarity found between the novel organism and representatives of known species of the genus Saccharopolyspora, i.e. $98.7 \%$ (S. antimicrobica) to $93.2 \%$ (S. thermophila), provide further evidence supporting the assignment of strain $\mathrm{W} 12^{\mathrm{T}}$ to this taxon.

The classification of strain $\mathrm{W} 12^{\mathrm{T}}$ within the genus Saccharopolyspora is supported by morphological and phenotypic characteristics. The novel organism is an aerobic, Gram-positive actinomycete and it forms an extensively branched substrate mycelium that fragments into irregular, non-motile, coccoid- and rod-shaped elements and carries sparse to moderate, white to buff aerial hyphae that differentiate into long chains of spores (with surfaces that were smooth or irregularly rough) (Fig. 1). The

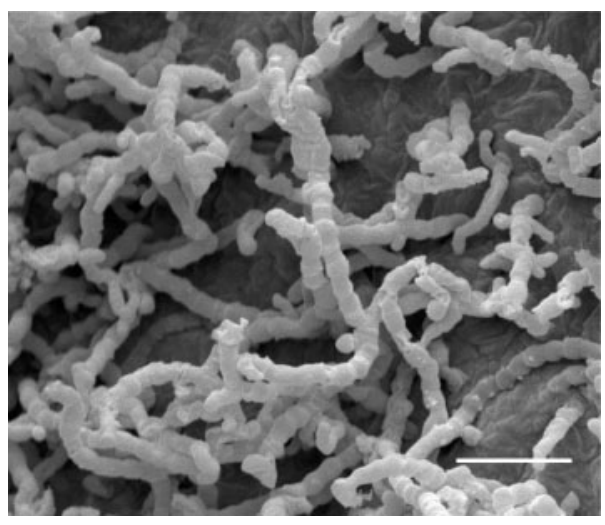

Fig. 1. Scanning electron micrograph showing long chains of smooth or irregularly rough-surfaced spores of a 14-day-old culture of strain $\mathrm{W} 12^{\top}$ grown on GYM agar at $28^{\circ} \mathrm{C}$. Bar, $5.0 \mu \mathrm{m}$. 
novel strain contained meso-diaminopimelic acid as the diagnostic diamino acid of the cell wall, whole-organism hydrolysates contained arabinose and galactose as diagnostic sugars (wall chemotype IV sensu Lechevalier \& Lechevalier, 1970), major amounts of phosphatidylcholine, phosphatidylglycerol and phosphatidylethanolamine were present (phospholipid type III sensu Lechevalier et al., 1977), tetrahydrogenated menaquinones with nine isoprene units were the predominant isoprenologues and dihydrogenated menaquinones with 10 isoprene units were minor isoprenologues. The non-hydroxylated fatty acid profile consisted of saturated, monounsaturated iso- and anteiso- components. The fatty acid profile was as follows: iso- $\mathrm{C}_{15: 0}$ $(25.8 \%)$, iso- $\mathrm{C}_{16: 0}(20.3 \%)$, iso- $\mathrm{C}_{17: 0}(15.1 \%)$, anteiso$\mathrm{C}_{17: 0}(10.7 \%), \mathrm{C}_{17: 0}(6.0 \%), \mathrm{C}_{17: 1} \omega 8 c(3.9 \%), 10$-methyl $\mathrm{C}_{17: 0}(3.8 \%)$, anteiso- $\mathrm{C}_{15: 0}(3.5 \%)$, iso- $\mathrm{C}_{14: 0}(2.9 \%), 10$ methyl $\mathrm{C}_{16: 0}(2.2 \%), \mathrm{C}_{15: 0}(1.6 \%), \mathrm{C}_{16: 0}(1.4 \%)$ and $\mathrm{C}_{18: 0}$ $(1.0 \%)$. The novel organism did not contain mycolic acids. In addition, the DNA of strain $\mathrm{W} 12^{\mathrm{T}}$ was rich in guanine and cytosine $(\mathrm{G}+\mathrm{C}$ content, $70.3 \mathrm{~mol} \%)$. All of these properties are consistent with classification of the novel isolate within the genus Saccharopolyspora.

As shown in Fig. 2, strain $\mathrm{W} 12^{\mathrm{T}}$ forms a monophyletic clade with the type strain of S. antimicrobica: the two organisms share $98.7 \% 16 \mathrm{~S}$ rRNA gene similarity. Strain $\mathrm{W} 12^{\mathrm{T}}$ is also closely related to the type strains of $S$. hirsuta subsp. hirsuta (97.7\% sequence similarity), S. shandongensis $(97.5 \%)$ and S. spinosa (97.4\%). DNA-DNA relatedness studies provide a reliable way of distinguishing between representatives of species that share high levels of 16S rRNA gene similarity (Goodfellow et al., 1998). In the present study, strain $\mathrm{W} 12^{\mathrm{T}}$ showed low levels of DNADNA relatedness with the type strains of $S$. antimicrobica
(56.3\%), S. hirsuta subsp. hirsuta (47.8\%), S. shandongensis $(25.5 \%)$ and S. spinosa $(21.7 \%)$; all of these values are well below the $70 \%$ cut-off point recommended for the assignment of organisms to the same genomic species (Wayne et al., 1987). A range of phenotypic properties serve to distinguish strain $\mathrm{W} 12^{\mathrm{T}}$ from recognized members of the genus Saccharopolyspora (Table 1).

The genotypic and phenotypic data show that strain $\mathrm{W} 12^{\mathrm{T}}$ merits recognition as a novel species of the genus Saccharopolyspora. The name Saccharopolyspora jiangxiensis sp. nov. is proposed for this new taxon.

\section{Description of Saccharopolyspora jiangxiensis sp. nov.}

Saccharopolyspora jiangxiensis (ji.ang.xi.en'sis. N.L. fem. adj. jiangxiensis referring to Jiangxi Province, China, the source of the grass-field soil from which the organism was isolated).

Gram-positive, aerobic, catalase-positive, non-acid-alcohol-fast, non-motile actinomycete. Produces extensively branched (0.4-0.7 $\mu \mathrm{m}$ diameter), colourless to buff substrate mycelium, which fragments in situ into coccoid- and rod-shaped elements after $3-4$ days at $28{ }^{\circ} \mathrm{C}$. White to buff aerial hyphae, $0.6-1.0 \mu \mathrm{m}$ in diameter, are produced upon prolonged cultivation on GYM agar. The organism also grows well on ISP3, ISP4 and modified Sauton's agar. The aerial mycelium carries long straight to flexuous chains comprising 6-10 spores (spore size 0.8-1.1 $\times 1.0-1.3 \mu \mathrm{m}$ ). The spore surface is smooth or irregularly rough. Diffusible pigments are not formed. Colony elevation is convex to irregular and colony margins are filamentous. Grows at 15$45{ }^{\circ} \mathrm{C}$ and $\mathrm{pH}$ 5.5-9.5. Degrades adenine, elastin, starch,

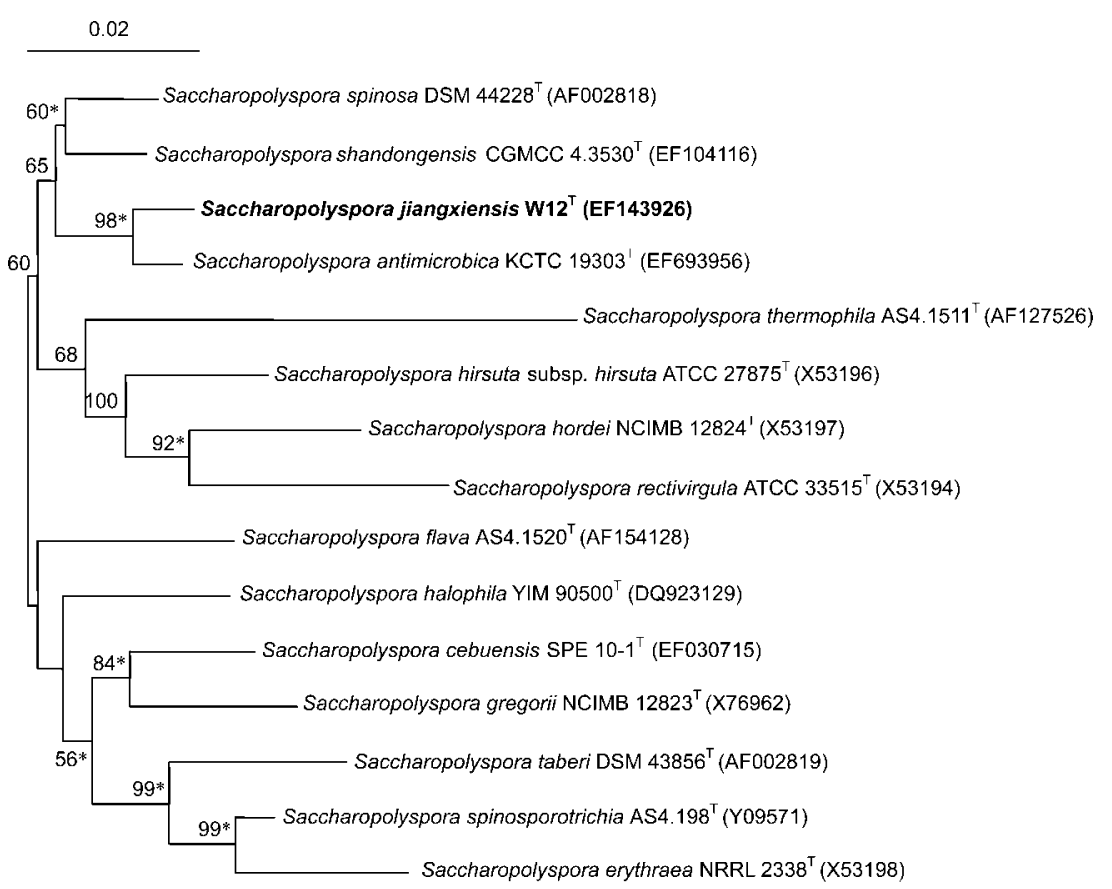

Fig. 2. Neighbour-joining phylogenetic tree, based on almost-complete 16S rRNA gene sequences, showing the relationships between strain $\mathrm{W}_{12}{ }^{\top}$ and the type strains of recognized species of the genus Saccharopolyspora. Asterisks indicate branches that were also recovered using the maximum-likelihood treemaking algorithm. Numbers at nodes indicate bootstrap percentages (based on a neighbourjoining analysis of 1000 resampled datasets); only values above $50 \%$ are shown. Bar, 0.02 substitutions per nucleotide position. 
Table 1. Comparison of properties of strain $\mathrm{W} 12^{\top}$ with those of recognized species of the genus Saccharopolyspora

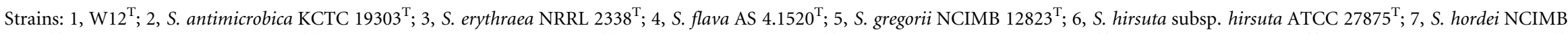

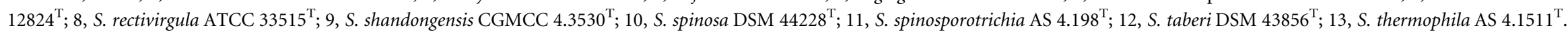

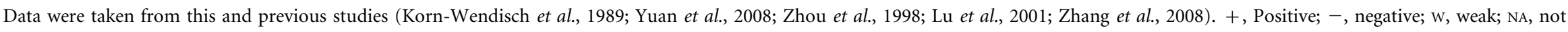

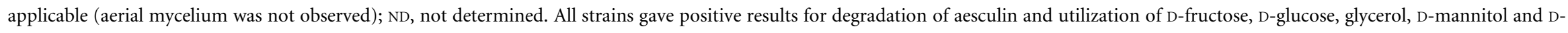
mannose as sole carbon sources.

\begin{tabular}{|c|c|c|c|c|c|c|c|c|c|c|c|c|c|}
\hline Characteristic & 1 & 2 & 3 & 4 & 5 & 6 & 7 & 8 & 9 & 10 & 11 & 12 & 13 \\
\hline $\begin{array}{l}\text { Spore arrange- } \\
\text { ment }\end{array}$ & $\begin{array}{c}\text { Straight to } \\
\text { flexuous } \\
\text { hyphae }\end{array}$ & Straight & Open spirals & Straight & $\begin{array}{c}\text { Hooks or } \\
\text { flexuous } \\
\text { hyphae }\end{array}$ & $\begin{array}{l}\text { Straight to } \\
\text { loose spirals }\end{array}$ & $\begin{array}{l}\text { Hooks and } \\
\text { spirals }\end{array}$ & Straight & Spiral & $\begin{array}{l}\text { Hooks and } \\
\text { open loops }\end{array}$ & Spirals & $\mathrm{NA}$ & $\begin{array}{c}\text { Hooks or } \\
\text { flexuous } \\
\text { hyphae }\end{array}$ \\
\hline $\begin{array}{l}\text { Spore orna- } \\
\text { mentation }\end{array}$ & $\begin{array}{l}\text { Smooth or } \\
\text { irregularly } \\
\text { rough }\end{array}$ & Rough & Spiny & Smooth & Smooth & Hairy & Smooth & $\begin{array}{l}\text { Smooth or } \\
\text { irregularly } \\
\text { rough }\end{array}$ & Spiny & Spiny & Spiny & $\mathrm{NA}$ & Smooth \\
\hline $\begin{array}{l}\text { Spores on sub- } \\
\text { strate mycelium }\end{array}$ & - & - & - & - & - & - & - & + & - & - & - & - & - \\
\hline $\begin{array}{l}\text { Substrate } \\
\text { mycelium }\end{array}$ & Fragments & Branched & Branched & Fragments & Fragments & Fragments & Fragments & Branched & Fragments & $\begin{array}{c}\text { Fragments in } \\
\text { lipid media }\end{array}$ & Fragments & Fragments & Fragments \\
\hline \multicolumn{14}{|l|}{ Colour of:* } \\
\hline $\begin{array}{l}\text { Substrate } \\
\text { mycelium }\end{array}$ & C-Bf & W-Bf-P & $\mathrm{OY}-\mathrm{RBr}$ & $\mathrm{Y}$ & C-Bf & C-Bf & C-Bf & $\mathrm{Y}-\mathrm{O}$ & C-Bf & G-OY-Br & $\mathrm{Br}-\mathrm{R}$ & $\mathrm{C}-\mathrm{Y}$ & C-Bf \\
\hline $\begin{array}{l}\text { Aerial } \\
\text { mycelium }\end{array}$ & W-Bf & W & P-BrG-W & W & $\mathrm{W}-\mathrm{Y}$ & W & W-Y & W-light P & W & W-P & W-G & NA & W \\
\hline $\begin{array}{l}\text { Soluble } \\
\text { pigment }\end{array}$ & None & Bf-P-Br & Y-POBr & None & None & $\mathrm{R}-\mathrm{O}-\mathrm{Y}$ & None & None & $\mathrm{Br}$ & $\mathrm{C}-\mathrm{Br}$ & $\mathrm{Br}$ & $\mathrm{O}-\mathrm{R}$ & None \\
\hline \multicolumn{14}{|l|}{ Degradation of: } \\
\hline Adenine & + & + & + & + & - & + & + & - & + & - & - & + & + \\
\hline Casein & - & + & - & - & + & + & + & - & + & + & + & + & - \\
\hline Chitin & - & - & + & - & - & - & + & - & - & - & - & + & - \\
\hline Elastin & + & - & + & - & + & + & + & - & + & - & + & + & - \\
\hline Hypoxanthine & - & + & + & + & + & + & - & + & + & - & $\mathrm{ND}$ & + & - \\
\hline Starch & + & + & + & + & + & + & + & - & + & - & - & + & + \\
\hline Tyrosine & + & + & + & - & + & + & + & + & + & + & - & + & + \\
\hline Xanthine & + & - & + & + & + & + & + & + & + & - & + & + & - \\
\hline Urea & + & + & + & + & - & + & - & + & + & + & $\mathrm{ND}$ & + & + \\
\hline $\begin{array}{l}\text { Reduction of } \\
\text { nitrate }\end{array}$ & + & + & + & + & - & - & - & + & + & + & - & + & - \\
\hline $\begin{array}{l}\mathrm{NaCl} \text { tolerance } \\
(\%, \mathrm{w} / \mathrm{v})\end{array}$ & $<11$ & $\leqslant 7$ & $<5$ & $<7$ & 13 & $<7$ & $<13$ & $<10$ & $<7$ & $<11$ & $2-3$ & 7 & $<7$ \\
\hline $\begin{array}{l}\text { Temperature } \\
\text { range }\left({ }^{\circ} \mathrm{C}\right)\end{array}$ & $15-45$ & $20-45$ & $20-42$ & $28-37$ & $10-35$ & $25-50$ & $20-60$ & $37-63$ & $15-38$ & $15-37$ & $28-37$ & $20-45$ & $45-55$ \\
\hline
\end{tabular}




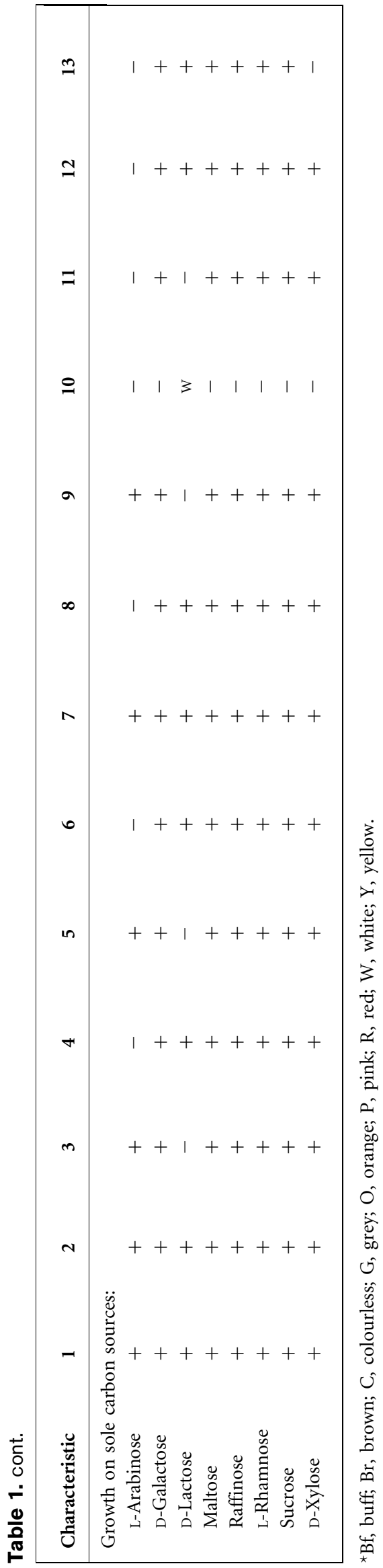

tyrosine and xanthine, but not casein, cellulose, chitin, guanine, hypoxanthine or xylan. Nitrate is reduced and aesculin, arbutin and urea are hydrolysed. Acid is formed from adonitol, $(+)$-D-arabinose, dextrin, $(+)$-D-fructose, $(+)$-D-galactose, $(+)$-D-glucose, glycerol, inulin, $(+)$ maltose, $(+)$-D-mannitol, $(+)$-D-mannose, $(-)$-D-ribose, $(+)$-sucrose and $(+)$-trehalose but not from $(+)$-Larabinose, $(+)$-cellobiose, ethanol, meso-erythritol, glycogen, myo-inositol, $(+)$-D-lactose, $(+)$-melezitose, $(+)$ melibiose, methyl $\alpha$-D-glucoside, $(+)$-raffinose, $\alpha$-L-rhamnose, (+)-D-salicin, (+)-D-sorbitol or $(+)$-D-xylose. Adonitol, (+)-D-arabinose, meso-erythritol, methyl $\alpha$-Dglucoside, myo-inositol, (+)-melezitose, (+)-D-sorbitol, $(+)$-trehalose, acetate, benzoate, citrate, fumarate, malate, succinate and tartrate are used as sole carbon and energy sources, but $(+)$-D-salicin, malonate and oxalate are not. Weak growth occurs in the presence of $\mathrm{NaCl}$ at $11 \%$, but not at $12 \%(\mathrm{w} / \mathrm{v})$. Resistance is shown to the following antibiotics ( $\mu \mathrm{g}$ per disc, unless indicated otherwise): lysozyme $(0.005 \%$, w/v); amoxicillin plus clavulanic acid (10); ampicillin (10), aztreonam (30); clindamycin hydrochloride (2); erythromycin (15); kanamycin sulphate (30); penicillin $\mathrm{G}(10 \mathrm{U})$; and tobramycin sulphate (10). Susceptible to ( $\mu \mathrm{g}$ per disc) amikacin (30), cefotaxime (30), chloramphenicol (30), ciprofloxacin (5), gentamicin sulphate (10), mezlocillin (75), ofloxacin (5), rifampicin (5), streptomycin sulphate (10) and tetracycline hydrochloride (30). Additional phenotypic properties are shown in Table 1. Chemotaxonomic properties are typical of the genus Saccharopolyspora. The fatty acid profile is as follows: iso- $\mathrm{C}_{15: 0}$, iso- $\mathrm{C}_{16: 0}$, iso- $\mathrm{C}_{17: 0}$, anteiso- $\mathrm{C}_{17: 0}, \mathrm{C}_{17: 0}$, $\mathrm{C}_{17: 1} \omega 8 c$, 10 -methyl $\mathrm{C}_{17: 0}$, anteiso- $\mathrm{C}_{15: 0}$, iso- $\mathrm{C}_{14: 0}, 10$ methyl $\mathrm{C}_{16: 0}, \mathrm{C}_{15: 0}, \mathrm{C}_{16: 0}$ and $\mathrm{C}_{18: 0}$. The DNA $\mathrm{G}+\mathrm{C}$ content of the type strain is $70.3 \mathrm{~mol} \%$.

The type strain, $\mathrm{W} 12^{\mathrm{T}}\left(=\mathrm{CGMCC} 4.3529^{\mathrm{T}}=\mathrm{JCM} 14613^{\mathrm{T}}\right)$, was isolated from a soil sample from a field of grass in Jiangxi Province, China.

\section{Acknowledgements}

This research was supported by the National Natural Science Foundation of China (NSFC; grant number 30570002) and by the Beijing Natural Science Foundation (grant number 5062024). The authors are grateful to Dr T. Kudo (JCM) for providing some of the type strains of Saccharopolyspora species.

\section{References}

Collins, M. D., Howarth, O. W., Grund, E. \& Kroppenstedt, R. M. (1987). Isolation and structural determination of new members of the vitamin $\mathrm{K}_{2}$ series in Nocardia brasiliensis. FEMS Microbiol Lett 41, 3539.

De Ley, J., Cattoir, H. \& Reynaerts, A. (1970). The quantitative measurements of DNA hybridization from renaturation rates. Eur $J$ Biochem 12, 133-142.

Embley, T. M. (1992). The family Pseudonocardiaceae. In The Prokaryotes, vol. 1, pp. 996-1027. Edited by A. Balows, H. G. Trüper, M. Dworkin, W. Harder \& K.-H. Schleifer. Berlin: Springer. 
Embley, M. T., Smida, J. \& Stackebrandt, E. (1988). The phylogeny of mycolate-less wall chemotype IV actinomycetes and description of Pseudonocardiaceae fam. nov. Syst Appl Microbiol 11, 44-52.

Felsenstein, J. (1981). Evolutionary trees from DNA sequences: a maximum likelihood approach. J Mol Evol 17, 368-376.

Felsenstein, J. (1985). Confidence limits on phylogenies: an approach using the bootstrap. Evolution 39, 783-791.

Felsenstein, J. (1993). PHYLIP (phylogeny inference package) version 3.6. Distributed by the author. Department of Genome Sciences, University of Washington, Seattle, USA.

Goodfellow, M. \& Orchard, V. A. (1974). Antibiotic sensitivity of some nocardioform bacteria and its value as a criterion for taxonomy. J Gen Microbiol 83, 375-387.

Goodfellow, M., Stainsby, F. M., Davenport, R., Chun, J. \& Curtis, T. (1998). Activated sludge foaming: the true extent of actinomycete diversity. Water Sci Technol 37, 511-519.

Gordon, R. E. \& Mihm, J. M. (1957). A comparative study of some strains received as nocardiae. J Bacteriol 73, 15-27.

Gordon, R. E., Barnett, D. A., Handerhan, J. E. \& Pang, C. H.-N. (1974). Nocardia coeliaca, Nocardia autotrophica, and the nocardin strain. Int J Syst Bacteriol 24, 54-63.

Hasegawa, T., Takizawa, M. \& Tanida, S. (1983). A rapid analysis for chemical grouping of aerobic actinomycetes. J Gen Appl Microbiol 29, 319-322.

Huß, V. A. R., Festl, H. \& Schleifer, K. H. (1983). Studies on the spectrophotometric determination of DNA hybridization from renaturation rates. Syst Appl Microbiol 4, 184-192.

Jahnke, K. D. (1992). BASIC computer program for evaluation of spectroscopic DNA renaturation data from GILFORD SYSTEM 2600 spectrophotometer on a PC/XT/AT type personal computer. J Microbiol Methods 15, 61-73.

Kämpfer, P. \& Kroppenstedt, R. M. (1996). Numerical analysis of fatty acid patterns of coryneform bacteria and related taxa. Can J Microbiol 42, 989-1005.

Kawato, M. \& Shinobu, R. (1959). On Streptomyces herbaricolor sp. nov., supplement: a simple technique for microscopical observation. Mem Osaka Unit Lib Arts Educ B Nat Sci 8, 114-119.

Kimura, M. (1980). A simple method for estimating evolutionary rates of base substitutions through comparative studies of nucleotide sequences. J Mol Evol 16, 111-120.

Korn-Wendisch, F., Kempf, A., Grund, E., Kroppenstedt, R. M. \& Kutzner, H. J. (1989). Transfer of Faenia rectivirgula Kurup and Agre 1983 to the genus Saccharopolyspora Lacey and Goodfellow 1975, elevation of Saccharopolyspora hirsuta subsp. taberi Labeda 1987 to species level, and emended description of the genus Saccharopolyspora. Int J Syst Bacteriol 39, 430-441.

Lacey, J. \& Goodfellow, M. (1975). A novel actinomycete from sugar cane bagasse: Saccharopolyspora hirsuta gen. et sp. nov. J Gen Microbiol 88, 75-85.

Lechevalier, M. P. \& Lechevalier, H. A. (1970). Chemical composition as a criterion in the classification of aerobic actinomycetes. Int J Syst Bacteriol 20, 435-443.

Lechevalier, M. P. \& Lechevalier, H. A. (1980). The chemotaxonomy of actinomycetes. In Actinomycete Taxonomy, Special Publication 6, pp. 227-291. Arlington, VA: Society for Industrial Microbiology.

Lechevalier, M. P., De Bièvre, C. \& Lechevalier, H. A. (1977). Chemotaxonomy of aerobic actinomycetes: phospholipid composition. Biochem Syst Ecol 5, 249-260.

Lu, Z., Liu, Z., Wang, L., Zhang, Y., Qi, W. \& Goodfellow, M. (2001). Saccharopolyspora flava sp. nov. and Saccharopolyspora thermophila sp. nov., novel actinomycetes from soil. Int J Syst Evol Microbiol 51, 319-325.

Marmur, J. \& Doty, P. (1962). Determination of the base composition of deoxyribonucleic acid from its denaturation temperature. $J \mathrm{Mol}$ Biol 5, 109-118.

Minnikin, D. E., Alshamaony, L. \& Goodfellow, M. (1975). Differentiation of Mycobacterium, Nocardia and related taxa by thin-layer chromatographic analysis of whole-organism methanolysates. J Gen Microbiol 88, 200-204.

Minnikin, D. E., O’Donnell, A. G., Goodfellow, M., Alderson, G., Athalye, M., Schaal, A. \& Parlett, J. H. (1984). An integrated procedure for the extraction of bacterial isoprenoid quinones and polar lipids. J Microbiol Methods 2, 233-241.

Mordarska, H., Mordarski, M. \& Goodfellow, M. (1972). Chemotaxonomic characters and classification of some nocardioform bacteria. J Gen Microbiol 71, 77-86.

Rainey, F. A., Ward-Rainey, N., Kroppenstedt, R. M. \& Stackebrandt, E. (1996). The genus Nocardiopsis represents a phylogenetically coherent taxon and a distinct actinomycete lineage: proposal of Nocardiopsiaceae fam. nov. Int J Syst Bacteriol 46, 1088-1092.

Saitou, N. \& Nei, M. (1987). The neighbor-joining method: a new method for reconstructing phylogenetic trees. Mol Biol Evol 4, 406425.

Sasser, M. (1990). Identification of bacteria by gas chromatography of cellular fatty acids, Technical Note 101. Newark, DE: MIDI Inc.

Shirling, E. B. \& Gottlieb, D. (1966). Methods for characterization of Streptomyces species. Int J Syst Bacteriol 16, 313-340.

Stackebrandt, E., Rainey, F. A. \& Ward-Rainey, N. L. (1997). Proposal for a new hierarchic classification system, Actinobacteria classis nov. Int J Syst Bacteriol 47, 479-491.

Thompson, J. D., Gibson, T. J., Plewniak, F., Jeanmougin, F. \& Higgins, D. G. (1997). The CLUSTAL_X windows interface: flexible strategies for multiple sequence alignment aided by quality analysis tools. Nucleic Acids Res 25, 4876-4882.

Warwick, S., Bowen, T., McVeigh, H. \& Embley, T. M. (1994). A phylogenetic analysis of the family Pseudonocardiaceae and the genera Actinokineospora and Saccharothrix with 16S rRNA sequences and a proposal to combine the genera Amycolata and Pseudonocardia in an emended genus Pseudonocardia. Int J Syst Bacteriol 44, 293-299.

Wayne, L. G., Brenner, D. J., Colwell, R. R., Grimont, P. A. D., Kandler, O., Krichevsky, M. I., Moore, L. H., Moore, W. E. C., Murray, R. G. E. \& other authors (1987). International Committee on Systematic Bacteriology. Report of the ad hoc committee on reconciliation of approaches to bacterial systematics. Int J Syst Bacteriol 37, 463-464.

Wu, C., Lu, X., Qin, M., Wang, Y. \& Ruan, J. (1989). Analysis of menaquinone compound in microbial cells by HPLC. Microbiology [English translation of Microbiology (Beijing)] 16, 176-178.

Yuan, L.-J., Zhang, Y.-Q., Guan, Y., Wei, Y.-Z., Li, Q.-P., Yu, L.-Y., Li, W.-J. \& Zhang, Y.-O. (2008). Saccharopolyspora antimicrobica sp. nov., an actinomycete from soil. Int J Syst Evol Microbiol 58, 1180-1185.

Zhang, J., Zhang, Y., Xiao, C., Liu, Z. \& Goodfellow, M. (2002). Rhodococcus maanshanensis sp. nov., a novel actinomycete from soil. Int J Syst Evol Microbiol 52, 2121-2126.

Zhang, J., Liu, Z. \& Goodfellow, M. (2003). Nocardia caishijiensis sp. nov., a novel soil actinomycete. Int J Syst Evol Microbiol 53, 999-1004.

Zhang, J., Wu, D., Zhang, J., Liu, Z. \& Song, F. (2008). Saccharopolyspora shandongensis sp. nov., isolated from wheat-field soil. Int J Syst Evol Microbiol 58, 1094-1099.

Zhou, Z. H., Liu, Z. H., Qian, Y. D., Kim, S. B. \& Goodfellow, M. (1998). Saccharopolyspora spinosporotrichia sp. nov., a novel actinomycete from soil. Int J Syst Bacteriol 48, 53-58. 